\title{
MAKING DRONES TO KILL CIVILIANS: IS IT ETHICAL?
}

\section{Edmund F. Byrne}

\begin{abstract}
A drone industry has emerged in the US, initially funded almost exclusively for military applications. There are now also other uses both governmental and commercial (in the US and abroad). Many military drones are still being made, however, especially for surveillance and targeted killings. Regarding the latter this essay calls into question their legality and morality. It recognizes that the issues are complex and controversial, but less so as to the killing of non-combatant civilians. The government using drones for targeted killings maintains secrecy and appeals to non-traditional justifications. Most scholars who assess these killer drone practices support citizen immunity, either by favoring a modified just war theory that prioritizes civilians' right to life or by challenging official deviations from applicable laws. They accordingly declare such killing immoral if not a war crime. The manufacturers of these killer drones are not themselves the killers, but they are abetters, i.e., sine qua non facilitators. So, I argue, any company concerned about its corporate social responsibility should cease manufacturing them.
\end{abstract}

\section{Keywords Drones Targeted killings Right to life Corporate social responsibility}

\section{Introduction}

An ethical stance is seldom unqualifiedly permissive if the matter at hand involves harm to innocent persons. In such a case - that is, one in which harm to innocent others is involved -the ethical stance commonly favors harm-limiting constraints if not outright prohibition. The constraint might be derived from a utilitarian calculus, e.g., to regulate rather than ban automotive transportation because, even though manufacturers and/or drivers may be insufficiently attentive to health and safety concerns, a transportation system generates many benefits. Or an outright prohibition may result from a society's conviction that certain behavior is unqualifiedly wrong, e.g., a Muslim society's Sharia-based ban on fornication or a ban in most US jurisdictions regarding possession/use of controlled substances. A sovereign government, though, might override a society's ban on something, claiming it must do so in the national interest. In that instance parties who would otherwise be deemed subject to the prohibition at issue, e.g., manufacturers, might be exempted. In opposition to one such appeal to the national interest, I question the justificatory claims made in behalf of manufacturing and selling a class of Unmanned Aerial Vehicles (UAVs), commonly called drones, if and because used for killing civilians, even outside any designated warzone.

In addressing this issue, I first acknowledge that ethical constraints on military equipment providers (except, say, regarding their business integrity) are commonly deemed 
inappropriate if not traitorous. It may be argued that a company ensconced in the military industrial complex might in some instance be at least circumstantially unethical (Byrne, 2010). But the prevailing opinion with regard to war-oriented products is that their manufacturers cannot be judged by the ethical standards applicable to makers of peace-oriented products. For, it is claimed, in international law a nation-state engaged in war is not bound by many of the constraints of traditional ethics.

Taken as it stands, this exceptionalist stance precludes the need not only for voluntary abstentions but even for treaties that introduce some constraints on the possibility of species annihilation. Fortunately, that has not kept countries with nuclear and other WMDs from entering into mutually advantageous agreements to increase the likelihood of human survival. However, no such constraint has yet been imposed on the latest killing technology, namely, lethal drones (see Falk 2015). Increasingly, however, people writing on this subject are sensitive to its legal and ethical aspects. Drawing on their thoughts, the following observations do call for ethical constraints on the use and therefore the marketing of military-oriented killer drones. Because the military component of this industry is still located largely in the United States, my focus is there.

\section{The current place of drones in and beyond the American economy}

From its onset at the beginning of this century, the drone industry was largely funded by and for the military. Its budget for drones is still over $\$ 500$ million annually; but now both military and commercial uses are generating new companies and new products. Many of these are intended for military use (Benjamin 2013, pp. 31-54). Some remain unpurchased (Pasztor 2015). Yet, according to one often-cited forecast (conducted by aerospace research company Teal Group Corp., in 2013) sales of civilian and military drones around the world may grow from the current $\$ 5.2$ billion a year to $\$ 89$ billion by 2023 . In this climate, the possibility of running an ethical drone business becomes more feasible (Loewenstein 2014). However, there remain many concerns about the envisioned uses of drones. These have to do especially with domestic safety and privacy, because drones do interfere with manned flights and with activities of individuals on the ground. So a current problem in the United States is to set appropriate limits on how drones may be used.

The Federal Aviation Administration (FAA) is expected to implement comprehensive regulations for the use of UAVs sometime in 2016. In the meantime, beginning in September 2014, the FAA has been issuing so-called Section 333 exemptions that permit companies to operate drones commercially. There are now over 700 companies that have a 333 exemption, and as many as 50 more are being added every week. ${ }^{i}$ In addition, the FAA has approved six drone test centers to develop certification standards and procedures for operating them within the air-traffic system (Pasztor 2013); and a registration system is to be operational by the end of 
2015 (Nicas and Pasztor 2015)

Urging the FAA to complete the integration of drones into the economy as speedily as possible are various corporate organizations, notably the Association for Unmanned Vehicle Systems International (AUVSI). According to this group agricultural applications will dwarf all other categories to the tune of $\$ 75.6$ billion by 2025 (Dillo 2013). On a global scale, according to another report, " $(\mathrm{t})$ he market for commercial/civilian drones will grow at a compound annual growth rate (CAGR) of 19\% between 2015 and 2020, compared with 5\% growth on the military side." This growth will be localized in "a handful of industries: agriculture, energy, utilities, mining, construction, real estate, news media, and film production." And major participants in this growth include "Switzerland-based senseFly (owned by France-based Parrot), Canadian firm Aeryon, publicly traded Swedish firm CybAero, Shenzen, China-based DJI, and Koreabased Gryphon." (Business Insider 2015)

Alongside the commercial applications noted above, drones are also being used for all sorts of government purposes, e.g., to locate illegal border crossers, lost hikers on mountain trails, or suspects in urban neighborhoods. Moreover, as the use of military drones is now winding down in Afghanistan and Iraq, "drones formerly reserved for battle missions are now landing in a kinder, gentler sector of commercial or humanitarian use" (Reagan 2015).

In short, drones currently available have a wide variety of functions, many of which are commendable albeit not easily integrated into the transportation complex we now inhabit. Assuming such integration is achievable, there may come a time when most drones are carrying out primarily civilian functions. Funding for drone research and utilization, though, still comes largely from military allocations. These in turn are made at the behest of elected officials whose objective, like that of the military industrial complex writ large, is to accommodate the interests of drone makers located in the areas the officials represent. In the United States, this distribution process is carefully managed and fostered by a Congressional Drone Caucus (Benjamin 2011, pp. 76, 215) which, like the broader weapons complex, is strongly biased in favor of using what is produced (Benjamin 2011, pp. 155, 217). And to date the principal military uses have been surveillance and targeted killing.

Surveillance has long been important to military strategists, and now this surveillance can be fine-tuned by use of drones. Some surveillance drones are very advanced, can be armed with missiles, and are extremely expensive. But Insitu, a Boeing subsidiary, produces a small unarmed surveillance drone that sells for a mere $\$ 100,000$ each. This drone, called a ScanEagle, has a 1.9 horsepower engine that can keep it airborne for 24 hours at a cruising speed of 48 knots; and it can carry a video camera with night vision and a thermal imaging system. As of January 2013 the U.S. Defense Department had some 250 ScanEagles in operation (Shanker, 2013).

Targeted killing is obviously more controversial than surveillance, especially outside the 
US. Most Americans, however, support using drones to kill individuals who are threats to their country's national interests (Cronin 2015, p. 112; Dudziak 2015, p. 175). The killing of foreigners is understandably unpopular in the country where the killing is effectuated but less so in the US. If a US citizen is targeted, media-attentive Americans are upset; but they are encouraged to appreciate the counterterrorist need for such tactics. The program itself has in any event become quite extensive.

Drones were proposed in 1964, then developed for military use in Israel, which directed them against Egypt in 1975 and Syria in 1982. Then in the 1990s the US began using drones for intelligence, surveillance, and reconnaissance (ISR), e.g., over Bosnia in 1995 (Newcome 2004), which had been produced by San Diego based General Atomics Aeronautical Systems, Inc. (GA-ASI for short) (Chamayou 2015, pp. 21-24). It has since received billions of tax-payer dollars, and is presently developing Avenger, a jet-powered drone (Woods 2015a, p. 27). This company first came into prominence during the Clinton administration when CIA director James Woolsey inter-connected his agency's talents with those of GA and the Pentagon's newly established Defense Airborne Reconnaissance Office (DARO) to develop GA's Gnat prototype into what became the Predator.

At the outset the principal US military UAVs were the older Predator MQ-1 and the more advanced Reaper MQ-9, both of which are now being replaced by still more advanced devices. Together they carried out some 2,500 drone strikes of which some two-thirds were on the conventional battlefields of Afghanistan, Iraq, and Libya (Woods 2015a, pp. 3-4). For killing missions they typically carry and release Hellfire missiles, which are lightweight (154 lb.) antitank weapons that can be laser-guided onto their targets (Woods 2015a, pp. 39-40). It was unarmed Predators that provided the ISR over Bosnia; and after Bosnia new technology did away with the need for pilots and analysts to be stationed near the battlefield (pp. 32-35).

Next, roughly from the beginning of this millennium, the US government took the lead in funding and developing a full-fledged killer drone program. The two principal agencies involved in military drone use are the CIA, outside of war zones, and the US Air Force. With remoteness no longer a problem, the former's drone program is administered by Distributed Ground System (DGS) One, which is based at Langley Air Force Base in Virginia, and at locations on several continents. The latter is watched over by the Combined Joint Special Operations Task Force, located at Bagram Air Base in Afghanistan, and the Air Force Special Operations Command, located at Cannon Air Force Base in New Mexico. CIA operatives employed or contracted with are civilians; but the actual running of killer drones is supposedly done under $\mathrm{CIA}$ jurisdiction by Air Force members of the $17^{\text {th }} \mathrm{RS}$ (Reconnaissance Squadron), which is located at Creech Air Force Base near Las Vegas. On September 7, 2000, DGS One at Langley started "Afghan Eyes" to do ISR in Afghanistan. Five years later elite airmen in the Air Force Operations Command were chosen for an independent drone force to be called the $3^{\text {rd }}$ 
Special Operations Squadron and over time they were equipped with their own MQ-1 fleet. A year after that the Special Operations Command (USSOCOM) placed its entire drone intelligence program into a Florida-based entity called the $11^{\text {th }}$ Intelligence Squadron which within two years was handling half of all videos from major battle zones (Woods 2015a, pp. 7780). While this ISR work was taking off in Florida, though, the Las Vegas area program came to dominate the drone killing program. This program, unfortunately, has taken off as well, with consequences of considerable magnitude, notably in regard to targeted killing.

To show this program's effects on humans, Chris Woods (2015a) interviewed many currently or formerly involved individuals, whether on the sending or receiving end, whether safely ensconced in the US, the UK, or wherever, or whether in an officially identified warzone or in any extra-warzone place where a subject of US or others' disapproval is being targeted. His findings raise serious issues with regard to the presuppositions at work in the process of selecting targets be they deemed civilians or not. I will next focus on strategic and sociocultural issues, drawing on Woods (2015a) and Ahmed (2013); then I will examine underlying legal and ethical issues.

\section{Strategic objections to using drones to kill civilians}

When the US began using military drones for targeted killing, it introduced many complexities as to the legitimacy of its actions. With respect to international and humanitarian law in particular, only two key target areas were clearly designated warzones, namely, Afghanistan and Iraq; others - Palestine, Yemen, Pakistan, Libya, and Somalia - were not. Key operatives throughout this emerging program were the American CIA and Air Force and several allied agencies especially in the UK. Earlier bans on such killings were modified during George W. Bush's second term; and then the Obama administration elevated the program into a major component of its foreign policy, where it remains to this day.

When drones first became viable killing instruments, the US used them against its enemies of the moment, namely, Afghan insurgents and their Pakistani allies. In 2005, though, drones killed two Spaniards and their families and subsequently two Canadians in Waziristan. At some point, probably in 2008, George Bush and Dick Cheney loosened restraints on targeting Westerners (Woods 2015a, pp. 131-133). In 2009 Obama took office and Westerners became fairly common targets (pp. 289-290). In 2010 an Australian and a New Zealander were drone-killed, and a year later two Britons in Somalia. A year later Obama changed a longstanding policy in Iraq and directed that drones now be used there not just for surveillance but for targeted killings (p. 200).

Bypassing the question whether any targeted killings are justifiable as "proper" wartime behavior, I focus on drones killing civilians. Actually, concern for civilian lives has become an important policy consideration in recent years. Most relevant data are kept secret, but on 
occasion damning facts emerge. A microcosm of the issue is a village in Yemen, where a US cruise missile killed 44 civilians just a week after Obama picked up his Peace Prize in Oslo. At the time up to 30 civilians could be killed without pre-approval; but in time that number was lowered to only 6 and then to 1 (Woods 2015a, pp. 240-241). These restraints fall by the wayside, however, if there is a Troops in Contact (TIC) situation. In such a case self-defense Rules of Engagement apply and Escalation of Force (EOF) is called for. Be it noted in this regard that British forces kill far fewer civilians than do US forces, partly because they follow stricter Rules of Engagement and use Reapers only on conventional battlefields (Woods 2015a, pp. 88-92, 246). As for US data, the UN has reported a tripling of civilian casualties year-onyear in 2013; but except for a brief period of openness the US Central Command (CENTCOM) has insisted that such information must be "classified in the interest of national security" ( $p$. 249).

The foregoing policies are at least rational, unlike the CIA's reliance on subterfuges when accused of causing civilian deaths. Its first line of defense is denial of charges and ridicule of anyone so charging. In 2011, though, an NGO presented evidence that the CIA had killed 390 civilians to date. The CIA didn't challenge that number but claimed that all deaths cited were of military-aged males (MAM). This label is dangerous to any person in a dronemonitored area who is a "voluntary human shield" or whom anyone that matters prefers dead. So also, however, is the effect such indiscriminate killing has on people living in an area subject to targeting; for, they take such mistreatment personally.

Revenge, of course, can't easily be inflicted on the distant operatives who activate these high-tech killings. But those targeted have mastered other ways to counterattack the drone brigades (Woods 2015a, ch. 12). Their main response to date has been to find and shoot or blow up spies on the ground. By 2009, their kills numbered over 100 in Pakistan and some 250 in Afghanistan (p. 271). Many were caught by means of specially developed tracking devices. A Russian product known as SkyGrabber also helps track older drones; and for those more advanced Al Qaeda is working on jammers that interfere with GPS signals and infrared tags and (why not?) on their own drones (pp. 274-275). They also attack close-to-target Allies' bases, e.g., a US naval base in Karachi, a British camp in Helmond province, and another facility in Yemen. At times, the retaliatory linkage is straightforward, e.g., after the CIA allegedly killed 80 students, mostly children, in Chenagai, Pakistan, a suicide bomber retaliated by killing 42 Pakistani soldiers in Dargai (pp. 93-96).

Because people being targeted develop a negative attitude towards the responsible US (or other) government, a number of former drone operatives brand the mainstream US drone killing policy a strategic blunder if as claimed its leaders really do want to win hearts and minds. In fact, at the very outset of the program, the head of British intelligence predicted this outcome (Mayer 2008, p. 41). Even less defensible, it would seem, are killings effected without regard 
to any military confrontation as such, that is, with no US boots on the ground. The US government, however, takes this non-event as justification for not seeking Congressional approval for its actions in accordance with the post-Vietnam War Powers Resolution (Dudziak 2015, pp. 177-178). But be it justified or not, its data differs widely from that of outsiders regarding civilian fatalities (Woods 2015b). These have engendered controversy, especially because of instances in which Western, including US, citizens have been targeted.

There are legal and even constitutional objections to killing Western and in particular US citizens. There are also intrinsic problems associated with drone killing of civilians in general. These include: (gradually ameliorated) indifference to civilian fatalities (especially on the part of the CIA in Pakistan); the psychological and emotional effect of remote killing work on the personnel so engaged; the inevitable tendency of targeted killing of civilians to arouse countermeasures that cost American lives; and the pro-human rights UN and international NGOs' condemnation of the killing of civilians, especially those located beyond any designated battlefield. In response to all this, the US government adamantly defends its globally scattered killings as being in America's national interest.

This imperial policy represents a drastic change from the far more restrictive policy that had been in place since President Gerald Ford's Executive Order 11905 placed a ban on assassinations by US agencies. This ban left a loophole for proxy killings by contractors; but eventually Presidents Ronald Reagan and Jimmy Carter extended the ban to them as well (Woods 2015a, p. 47). Operating under these constraints, President Clinton was told precisely where he could have Osama bin Laden killed; but his Department of Justice refused to authorize the action. Then Clinton's successor removed the restraints. Upon taking office Bush II prepared killing authorizations then had them enacted soon after the 9/11/2001 catastrophe (Mayer 2008, p. 32, 37-39). Egged on by senior counterterrorism official Cofer Black (Mayer 2008 , pp. 12, 29, 40), they initiated a so-called global war on terror which they alleged was neither type of war recognized by international law, i.e., (1) between two or more sovereign states or (2) between a nation-state and insurgents within its borders (p. 63). Within a week of 9/11 Congress passed the Authorization for Use of Military Force Against Terrorists (AUMF), which claims

That the President is authorized to use all necessary and appropriate force against those nations, organizations, or persons he determines planned, authorized, committed, or aided the terrorist attacks that occurred on September 11,2001 , or harbored such organizations or persons in order to prevent any future acts of international terrorism against the United States by such nations, organizations or persons.

Though aimed literally just at "nations, organizations, or persons" involved in 9/11, the AUMF by not restricting "persons" to any locale has become the basis for increasingly widespread and 
controversial targetings (Greenberg 2015, p. 75).

This is manifest, for example, in Obama counterterrorism specialist John Brennan's 2012-04-30 speech entitled "The Ethics and Efficacy of the President's Counterterrorism Strategy." Shortly after that speech, 26 lawmakers complained that civilian lives were at risk because "our drone campaigns already have virtually no transparency, accountability or oversight." This eventually inspired Obama to release a rigorous-sounding document entitled "U.S. Policy Standards and Procedures for the Use of Force in Counterterrorism Operations Outside the United States and Areas of Active Hostilities." By then, however, the process of selecting drone targets had been brought into the White House, where Brennan's staff proposed and Obama himself did the choosing. Many knowledgeable experts including former drone operators are critical of targeting individuals who are outside any clearly designated warzone (Woods 2015a, pp. 285-287). In response to such criticisms, however, Obama spokespersons say the deaths in question aren't war-related because the US has no troops on the ground where they occurred (p. 208). Moreover, they counter any attempt to challenge the program in court with maximum "obstruction and obfuscation" (p. 284).i"

This self-serving stance trivializes the horrendously complex issues that this century's conflicts have created with regard to war (O'Connell 2012). And its systematic narrowmindedness may also be strategically short-sighted, because today's drone targets are to a large extent determined by foreign balance of power arrangements that may well change in the future.

\section{Socio-cultural objections to using killer drones against civilians}

Non-combatant immunity is a fundamental norm of international law (Gardam 1993); and majorpower drone killing is hard to justify as self-defense against an asymmetrical target (Finklestein et al, eds., 2012). So, much of what is being said about people harmed by drone attacks is users' rhetoric (see, however, Living under Drones 2012, and Cortright et al. 2015). To counter this verbal smokescreen, anthropologist Akbar Ahmed (2013) focuses on the complex conflicts between government centers and peripheral tribes both before and after 9/11. His objective: to show that US assumptions regarding these conflicts are faulty, and to warn that changes in policy and practice must be made if tribal groups are to survive as groups.

His book's title, Thistles and Drones, consists of symbols for forces competing (a) to advance the well-being of people who rely on tribal hegemony (thistles) or (b) to undermine in its entirety (via drones) any power such tribal people might have. First Ahmed describes the nature of tribes, their take on Islam, tensions among the Waziristan tribes of western Pakistan, and the key distinction between center and periphery that Pakistani leaders have sought to balance. Then he shows how post-9/11 US policies have simplistically backed nation-state centers against peripheries with disastrous consequences. 
A tribe, says Ahmed, is "a unit of ethnic, social, and political organization in which kinship is the defining principle of social organization and interaction" (p. 18). The most successful tribes operate within a segmentary lineage system, which includes a tribe and a territory, and maintains tribal identity via a code of honor and a law of hospitality. Ideally, it has egalitarian genealogy, male cousin rivalry, a council of elders, and a distinctive language (pp.

18-19). Tribal links to Islam are based on a "fictitious genealogy"; and "tribal Islam practiced by largely illiterate tribesmen is antithetical in every way . . . to fundamentalist or liberalist versions of Islam" (pp. 28, 30).

These tribal arrangements are centuries-old; but nation-states, colonies, and socialist republics have routinely ignored them. And thus have the tribes become peripheral to the political center of the country or colony in which they are located. Yet if they rebel they become the poorly armed targets of whatever social system, say a hostile tribe, controls the center and maintains that control with comparatively modern weaponry. This advantage of the controlling center has been further exacerbated post-9/11 by the US's practice of supporting a centercontrolling groups that declares a peripheral tribe to be linked to terrorists, notably al Qaeda.

Consider first the violence-generating scenario in the Waziristan area of western Pakistan. The Waziristan tribes had for ages managed their affairs with a tribal elder, a religious leader, and the political agent representing the central government (Ahmed 2013, p. 49). The British, in control until 1947, were tolerant of this quasi-autonomous system. But when Pakistan assumed control it fostered a modern, nationalist version of Islam whereas the local mullah favored a traditional and tribal version. Yet he aided the Pakistani center by training students ("taliban") who joined the Afghan mujahideen against the Soviet troops. When the latter pulled out in the late 1980s the young taliban formed a group that opposed Northern Alliance forces in Afghanistan not associated with their tribe. When the US invaded Afghanistan after 9/11 it overthrew the Taliban and persuaded Pakistani president Musharraf to invade the Waziristan region. Over the next decade bilateral brutality ran rampant. The government stormed a mosque and this led to the founding of the Tehrik-e-Taliban Pakistan (TTP) in 2007. Then others formed the Mugami Alliance to oppose the TTP as being "bad" Taliban. The US thereupon posted drones over Waziristan and, disregarding the Pakistani distinction between good and bad Taliban, targeted them all. Especially horrific: a drone strike on a tribal jirga in Datta Khel (March 2011) that killed 44 people, none of whom was a combatant.

Thus is the Waziristan tribal system being systematically undermined - in spite of efforts by newcomer Osama bin Laden to reverse its decline. Raised in Yemen in accordance with Islamic and (Qahtan) tribal values, he came to favor the tribal concept of revenge over the Islamic preference for forgiveness and atonement. He then broke with his teacher/mentor in Afghanistan and backed the militant Pukhtun warriors against the non-Pukhtun tribes embraced by the Northern Alliance. Acting tribally, says Ahmed, they "constitute themselves as a raiding 
party, based on the genealogical charter and motivated by notions of revenge and honor ... The Islamic element is conspicuous by its absence . . ." (p. 108).

This depreciation of Islamic values Ahmed attributes to Saudi Arabia's intrusion into the Asiris' country. Formed in 1932, Saudi Arabia annexed most of Asir two years later, then sent in Wahhabi clerics to replace the local people's religion with their own. This led bin Laden to form al Qaeda ("the base") in 1988, whereupon the Saudi government stripped him of his Saudi citizenship and began besieging Yemenis in Saudi Arabia. Undeterred, the Asiris perpetrated the 9/11 attack, merged al Qaeda in Saudi Arabia with the organization in Yemeni, and engaged in other terror attacks elsewhere. Yet to be resolved in this and other countries: how to strike a balance between center and periphery. Historically, however, balance has not been a prominent objective.

During the colonial era the occupying country often ruled tribes harshly. The British are the main exception, having learned that they could maintain "relative stability" via indirect rule. Other colonizers preferred "the steamroller," as did the Russians in suppressing the Circassians in the Caucasus, where they killed 1.5 million and displaced as many more to the Ottoman Empire. French colonizers ruling Algeria killed 45,000 people, mostly of the Kabyle Berber tribe, during the nineteenth century and a million and a half more during the Algerian war of independence. Spain was equally brutal in Morocco, as was Italy in Somalia and Libya. The Netherlands killed some 100,000 Aceh people in Indonesia. Meanwhile the Ottoman Turks tried without success to rule the Kurds, especially in Yemen.

When colonization ended after WW II, dominant local groups took control of their center and proceeded to oppress the periphery with impunity. The resulting arrangements Ahmed sorts into five different models. I: a strong Muslim center with Muslim segmentary lineage societies on periphery, e.g., Turkey, Iran, Iraq, and Syria vs. the Kurds. II: tribal monarchies, e.g., in Afghanistan, Albania, and Iraq (all now defunct), and currently in Kuwait, Morocco, and Jordan. III: multiple tribal societies in one state (which is the case in most African nations), e.g., Libya, Nigeria, Cameroon, Ivory Coast, Guinea, and Gambia. IV: a modern state dominated by one segmentary lineage system, e.g., clans in Somalia, tribes in Yemen, and (post-USSR) the Teke tribe in Turkmenistan. V: non-Muslim centers with Muslim segmentary lineage peripheries. A key example is China, the center of which is dominated by Han (90\% of population, 1.3 billion people), but contains 55 minorities, many of which are Muslim. In Ethiopia different forces dominated at different times and each eagerly killed off its foes. The Somali, in four different countries, and the Albanians in Kosovo have each suffered systematic suppression, as have Muslim peripheries in east Asian countries.

Recent US and others' involvement in these conflicts has turned them into "a global war against tribal Islam" (Ahmed 2013, p. 260). Backing Saudi Arabia, the US has directed frequent drone attacks against two southern provinces of Yemen. On behalf of the central 
governments of Djibouti, Ethiopia, and Kenya, it has turned its CIA and Special Forces against Somalis associated with al Shabab ("the youth") and the system of Islamic courts they now maintain. It directs drones against the Kurdistan Workers' Party (PKK) because President Bush accepted Turkey's branding it a "common enemy." When Indonesians of Yemeni descent in the Philippines formed Abu Sayaf to defend themselves against the Philippine government's onslaughts, the US equated the group with al Qaeda and made them targets of drone strikes. It has also supported central government attacks on tribes in Algeria, Cambodia, and of course Pakistan.

This being the problem writ large, the solution, says Ahmed, is certainly not to explain the war on terrorism as a "clash of civilizations." For, by not transcending this over-simplification "the United States has been fighting the wrong war, with the wrong tactics, against the wrong enemy, and therefore the results can be nothing but wrong" (Ahmed 2013, p. 327). (Put less eloquently, one of the US's roles with regard to drone killing has been that of a hired gun.)

Assuming that Ahmed's data as to the fatalities and mass displacement that centers have inflicted on peripheries are approximately accurate, his account seriously challenges mainstream US accounts. For, the plight of traditional tribes is now arguably due less to intertribal rivalries than to superimposed priorities of global powers pursuing their own agenda. Meanwhile, the victims' bloody counter-attacks, though rooted in tribal codes, are themselves destructive of tribal systems.

Having now made a case that current use of drones to kill civilians is strategically and socio-culturally counter-indicated, I turn now to the legality and ethics of using drones to kill civilians and then to the ethics and CSR import of manufacturing drones that are to be used to kill civilians.

\section{Is it ethical to use drones to kill civilians?}

To provide a normative context for discussing the ethics of killing civilians, I will first note some relevant modern rules in international law, then recall historical failures in this regard and in current attitudes, then introduce several scholarly analyses which taken together support an assertion that the use of killer drones is undermining every vestige of traditional law and ethics regarding war.

In numerous documents duly ratified over two centuries, international law is forthright in condemning the killing of civilians as murder. The documents in question begin with the nineteenth century Lieber code (Mayer 2008, pp. 84-85) and include Hague and Geneva Conventions, which are collected and summarized by the International Committee of the Red Cross (ICRC) in its Customary IHL Rule 89: Violence to Life - Murder is prohibited. iii In traditional just war theory, it is referred to as the principle of discrimination, which forbids intentionally aiming to harm noncombatants (Fotion 2007, pp. 22-24 et al.). This rule is central 
to just war theory, and is appealed to repeatedly by scholars and others who would like it to be honored by all whose military mission includes killing. Its meaning, unfortunately, is not as clear as one might wish. The ICRC suggested that a person who has a "continuous combat function" (CCF), i.e., has been and may again be a combatant, may be killed - but only in case of necessity. Then a few years later it associated this rule with a civilian whose actions constitute "direct participation in hostilities"iv At issue here is clarifying the scope of the traditional rule of imminence, which specifies that to be targeted a person must be going to attack in the immediate future. In selecting its targets, however, the Obama administration deems imminent anyone who is generally engaged in terrorist activity against the US (Greenberg 2015, pp. 85-86; Welsh 2015, p. 39). This seriously narrows the scope of who is a noncombatant. Historically, however, the wellbeing of civilians has not been a priority consideration.

Throughout recorded history the killing of civilians has been a tool deliberately used to win a war. In ancient times everyone in a town might be killed. Later on, as towns built walls to protect their populations, such towns were besieged, a tactic that often involved deliberately starving the inhabitants. (Blockades to keep out food and medicines, e.g., as Saudi Arabia is currently maintaining against Yemen, are comparable.) Elimination of undesirable peoples was an ugly secondary aspect of World War I, and the Nazis gave it primacy in World War II. Also in that war the emergence of bomber aircraft led to saturation bombing, i.e., deliberate aerial targeting of civilian populations. This strategy was streamlined by the introduction of the atom bomb, which brought that war to an end precisely by decimating civilians whose principal fault was to be living in the wrong place at the wrong time. Over decades thereafter, the stockpiling of even more destructive civilian-targeting hydrogen bombs became major powers' allegedly defensive guarantee which they assiduously strive to keep non-possessors from duplicating.

In short, killing civilians has long been prohibited but now as in the past is included in the arsenal of military planners; so rules to the contrary must challenge not only the killings but how they are justified. In that respect, ordinary people remain largely acquiescent as to purported enemies. But many scholars find drone-targeted killing of civilians harder to justify than were past military methods of killing. Consider their reasoning.

As noted above, Bush II asserted after 9/11 that it was thereupon engaging in a global war on terror that corresponded to neither type of war recognized under international law. It being global, anyone anywhere can be targeted, they claimed, until the terrorist threat is eliminated once and for all. And it also claimed that detainees' right to habeas corpus was suspended for the same duration. There is no such global war, however (O'Connell 2004). And on June 12, 2008, the U.S. Supreme Court said as much in granting habeas corpus rights to detainees. ${ }^{\vee}$ But this restraint has not been applied to targeted killing, regarding which ethical concerns are less intense. 
Asked about the burgeoning use of drones to kill people be they civilian or whatever, some high level US government officials are reported to have replied in a joking manner (Benjamin 2013, pp. 60-61). Given this attitudinal context, it is not surprising that defenders of the UAV industry sometimes brush off the ethical issues others are raising with a paraphrase of the National Rifle Association's defense of gun owners' rights, saying drones don't kill people, people kill people. Cutting through this mercantile adage, Lev Grossman (2013) describes the normative issues surrounding U.S. drone killing as follows:

Bottom line: the U.S. seems to be struggling to adapt its $20^{\text {th }}$ century moral code of warfare to the $21^{\text {st }}$ century practice of sending flying robots into other countries to kill people. It appears that drones are evolving faster than Americans' ability to understand how, legally and ethically, to use them (p. 28).

This assessment is accurate with respect to identifying the legal and ethical issues, but not with respect to proposed correctives. Many related legal issues are being considered by international law scholars (e.g., Melzer 2008), including proposed regulations to govern use of killer drones (Zenko 2013; Recommendations and Report 2014). For, few accept, say, the US government's 60-word AUMF as a definitive justification of any and all drone killings. In particular, the words of the AUMF leave unexamined the assumption that it is ever morally justifiable to inflict harm on others even if they themselves are harmless. Peter W. Singer, for one, calls this assumption into question rhetorically by reference to Isaac Asimov's famous three laws of robotics: (First) a robot may not injure a human being or allow a human being to come to harm; (Second) a robot must obey orders given to it by human beings except when such orders conflict with the First Law; and (Third) a robot must protect its own existence, provided such protection does not conflict with the First or Second Law.

Reliance on these laws would be simplistic, of course, given that they are fiction, no technology exists to enforce them, and most funding of drone manufacturing is distributed by the military, which wants to use drones to kill people, civilians included (Singer 2009, pp. 422$423,425)$. In this vein, in a book containing the views of so-called military ethics specialists, every contributor declares drone killing ethical (Strawser 2013). It's unlikely, then, that they would agree with Singer that we "require new unmanned systems to have a 'human impact statement' before they enter production, analogous to the environmental impact statements now required of new consumer products and buildings" (Singer 2009, p. 427). In fact, any such constraint would run counter to US military policy, which recently became even less restrictive than before with regard to targeting civilians: drone targeters' instructions previously required them to "ensure" civilians are not targeted; now they are merely encouraged to "avoid targeting" civilians (Krieger, 2013).

Some experts not ensconced in a military world view are much more critical. In particular, several stress the conundrum one encounters by trying to determine whether drone 
killings are or are not acts of war: in the US, if they are acts of war they are unconstitutional because never fully authorized by Congress; if they are not acts of war they violate international law's prohibition of assassinations (Stefany, 2013; see also Philosophy of Science Portal, 2013). These random expressions of concern were given quasi-definitive form in 2014 when a task force made up of ten exceptionally expert members and three working groups issued their Recommendations and Report. This document, which focuses on development and use of lethal UAVs by the United States (p. 7), duly accredits the legality of the program. "But," they declare,

changing technologies and events have made it increasingly difficult to apply the law of armed conflict and the international law relating to the use of force in a consistent and principled manner, leading to increasing divergence between the law' and core rule of law principles that traditionally have animated US policy. . . . Basic categories such as 'battlefield,' 'combatant,' and 'hostilities' no longer have clear or stable meaning. . . . (D)espite the undoubted good faith of US decision makers, it would be difficult to conclude that US targeted strikes are consistent with core rule of law norms (p. 12; see also pp. 34-35).

Moreover, they warn, "increasing use of lethal UAV's may create a slippery slope leading to continual or wider wars" (p. 31; see also p. 37); and targeted individuals, notably in Pakistan and Yemen, lack the means to defend themselves by recourse to courts of law (p. 36). For these and other reasons, they call for increased transparency, oversight, and centralization of drone warfare under the military and not the secretive and unaccountable CIA.

In accord with such critiques of killer drone targeting, there are also a number of peace activists who favor regulating and eventually banning lethal drones altogether (van der Linden 2015; Benjamin 2013, pp. 165-200). Technical people involved in developing drones rarely share any such notion. But some robotics experts refuse to engage in any research that is directed to military objectives (Singer 2009, pp. 170-176). And, to repeat, some knowledgeable scholars have mounted detailed arguments against the use of killer drones, at least if used to kill civilians (see especially Cohn, ed., 2015). To complement these well researched and wisely reasoned objections, I will now elaborate supporting considerations from the ethical domain.

For centuries scholars have connected ethics and war via just war theory (JWT), which divides ethical issues regarding war into two components, one as to hostile objectives (jus ad bellum) and one as to hostile practices (jus in bello). Regrettably, belligerents came to use this theory routinely to justify their warmaking, so it fell into desuetude; then in the wake of the Vietnam War, Michael Walzer (1977) revived it. It has come to face seemingly insurmountable complications, though, because of how nontraditionally conflicts are now carried on (Byrne 2009).

There are, be assured, various proposals aimed at remedying this JWT crisis. Several 
scholars in effect deneutralize the JWT by replacing the moral equality of combatants with a good guy's "unilateral right to kill founded upon a concept of justa causa" (see Chamayou 2015, pp. 164-165). In sharp contrast, another scholar recommends replacing the theory with reasoned pacifism (Fiala 2008). Others say we should modify it, e.g., by taking into account the emergence of non-state belligerents and adding qualifications to both the legitimate authority and the likelihood of success principles (Fotion, 2007, p. 97). Harry van der Linden (2015), who is opposed to weaponizing drones, proposes to add five "jus ante bellum" principles that if adhered to would expand warmaking entities' openness to non-military problem-solving options (pp. 180-188). Kai Draper (2016), in turn, proposes basing the theory not on nation-state prerogatives but on the rights of (one or many) individuals and abandoning the traditional principle of double effect. Thus oriented, he confronts the targeting of individuals with a rather targeter-friendly account of the rights of individual bystanders (ch. 7). Even unauthorized violence, he says, may be excusable if those attacked are responsible for their plight by having assumed risk or have been compensated, or if the infringements on their rights are justifiable. More inherently liable, he contends, are combatants and military personnel, those who assist unjust aggressors, and munitions workers (ch. 9).

Each of these efforts to update JWT is intellectually stimulating; but taken together they are incompatible - except for one shared flaw. None seriously addresses the implications of an overarching indifference of the killer drone center of power, i.e., the US, to any restraints on its choice of targets. For, if they did, they would have to deal with a meta-problem that hovers over all their reasoning, namely, that war is no longer being strategized or fought in accordance with concepts and categories that JWT presupposes. This problem is addressed by Grégoire Chamayou (2016).

According to Chamayou, post-9/11 conflicts and policies have undermined most of the accepted norms of war. To begin with, the laws of war apply to a place where fighting takes place; but under the new dispensation, armed conflict becomes a mobile place attached to a person who may be targeted anywhere (pp. 55-59). This "dronized manhunting" represents a triumph of anti-terrorism over counterinsurgency (p. 69). And as drones become the warriors of choice, US "boots on the ground" become rare and the burden of risk shifts to the civilian populace (p. 77). So bravery and heroism, once key qualities of soldiers, become irrelevant. Distant drone assassins are in no danger, so a new virtue is being created for them out of the psychic damage they incur (Chamayou 2016, pp.96-105, 114-124). Insofar as military personnel do go to a conflict area, they are given-- insofar as possible - risk-free priority over civilians. This was in evidence over Kosovo, where NATO bombers flew at 15,000 feet, to the detriment of civilians (pp.128-130). This self-preference policy is based on the Israeli "ethic," which favors its soldiers over foreign civilians - in other words, "an evisceration of the principles of international law in favor of a nationalism of self-preservation" (pp. 130-134). 
De facto, drones eliminate combat reciprocity from warfare. Traditionally, war was understood to be a matter of human beings killing each other. By eliminating one side of this equation, drones remove distinction and proportionality from jus in bello and replace it with "an ethic for butchers or executioners, but not for combatants" (Chamayou 2016, pp.162-163). Nor can this one-sided advantage be justified by characterizing it as a police action, because police may use force only as a last resort, not as an up-front policy (pp. 167-171).

Ironically, the emergence of drones is resolving a contract theory problem that has troubled political scientists for centuries. The theory justifies government as the people's defender but obligates people to risk death if so ordered by their government. An inherent contradiction, to be sure, but it is surmounted if drones and locals do the dirty work (177-184). There's no time to relax, however, because a government so inclined could just as easily use its drones against its own people (195-204).

The key theoretical problem, then, is this: reconsiderations of JWT are incompatible and Chamayou's post-JWT analysis suggests we can't arrive at a humane solution without dethroning technological inevitability and committing the human race to a regime based on human rights. With this problem duly noted, I now articulate the implicit rationale for targeting civilians in this post-JWT age and argue for replacing that rationale with one that fully honors would-be victims' right to life.

The current drone killer's rationale: a person is targeted only if harmful to the interests of this country (say, the US) so long as he/she remains alive.

Three objections to this rationale:

(1) You claim this rationale is justified because the traditional rules of war do not apply to the random targeting of individuals who are located outside of any area where a nation-state is actively and substantially engaged in warfare.

But if the location of the target is not in a warzone then his or her being targeted cannot be justified as an act intended to advance that nation-state's quest for a military victory. Rather is such a targeting, however effectuated, an assassination. And given the vacuity of claims regarding a so-called global war, any such assassination is in violation of international and humanitarian law.

(2) A defender of the drone-targeting nation (but not its own spokespersons) might explain that it is so engaged because the majority of its people are opposed to any participation in the military that would place them personally at risk, and many others are unqualified to serve (Chamayou 2016, pp. 185-191; Anon. 2015). Faced with this socio-cultural challenge, the nation has to shift its approach to staffing needs from social to economic capital, i.e., to substitutes for human activity such as killer drones.

No doubt this is a serious economic problem for a government unaccustomed to seeking peaceful solutions to its perceived problems. But, historical evidence notwithstanding, 
economic necessity is not a justification for murder. And furthermore, if such extra-warzone targeting is part of some other objective of the nation-state, e.g., to gain control of an area with mineral wealth sought by that nation-state's corporate interests, the profit-facilitating nation-state should be subject to the same penalties as are or ought to be the corporate interests it is advancing (Byrne 2014).

(3) Even if a pertinent reason has been advanced for a particular extra-warzone targeted killing, that reason should usually be suspect given the intra-state conflicts at work when an opposing local interest identifies said target to the nation-state that carries out the assassination (Recommendations and Report 2014, p. 35). Such local conflicts constitute not an excuse but an additional reason to honor not only the would-be target's right to life but his or her right to a fair trial as well.

\section{Is it legal and ethical to produce drones that are used to kill civilians?}

For reasons spelled out above, a producer of killer drones cannot assume that its products will only be used responsibly in wars fought on honorable grounds. Least of all should said producer assume it needs no better reason than the shibboleth that drones don't kill people, only people kill people. For, even though there is disagreement among ethicists regarding the morality of killing in wartime (Norman 1995), there is nonetheless broad agreement that the targeted killing of civilians is not morally justified. This being the case, a company engaged in manufacturing drones for this purpose should be conjointly concerned about its failure to respect human rights under international law and about its failure to maintain its corporate social responsibility (CSR).

A fairly strong case can be made for saying that the provision of drones that are used to kill civilians is illegal under current international law. This case would be based primarily on rules of international law that have been considered above. And to these one can arguably add the Arms Trade Treaty of the United Nations (2014), which was signed 25 September 2013 and entered into force 24 December 2014. Some 230 countries are signatories of this treat, the US included. The concerns addressed by this treaty are straightforward and specific regarding weapons made and sold for use against noncombatants (ICRC 2014). It falls short of constituting a ban on current US policy, however, because it is aimed at international arms merchants and not at a sovereign state like the US that buys weapons from manufacturers wherever located and uses them itself or transfers them to others whom it chooses to support. It remains the case, however, that international law disfavors harming noncombatants; so a company that facilitates doing so is jeopardizing its CSR. Nor can it, for reasons stated above, whitewash its providing killer drones with post-9/11 claims that its products are responsible for "zero losses" (Chamayou 2016, p. 192).

To be sure, there are competing versions of CSR, and they don't all include an ethical 
dimension (Windsor 2006). But Carroll's (1991) widely respected set of defined cumulative responsibilities does include an ethical as well as a philanthropic dimension (see also Carroll 1999). Moreover, arms makers' CSR compliance may be criticized without appealing directly to an ethical dimension (Byrne 2007); and CSR liability claims against MNCs can and should be based on international human rights (Byrne 2014). In fact, an in-depth analysis of this very issue has been issued specifically with investor integrity in mind(Griek et al. 2014). On the basis of their thorough assessment of the killer drone industry the authors of this study have the following to say about Reputational Risks:

The use of drones in ways that violate human rights, such as for targeted killings outside recognised warzones, exposes companies to public criticism and allegations of complicity in human rights violations, with corresponding reputational risks. Investors in companies involved in drone production may, in turn, be exposed to these risks through their investments. Increasingly, investors are being held accountable for the human rights impacts of their investments [notes omitted]. ...

To limit their exposure to human rights and reputational risks, investors are encouraged to:

Remain aware of risks and keep abreast of legal and regulatory development;

Formulate a stance on drones, defining high-risk uses and high-risk end users;

Engage with companies to address the regulatory and human rightsrelated risks to which the companies are exposed (Griek et al. 2014, pp. 13-14).

These cautionary recommendations are, of course, financially oriented; but they are clearly based on sensitivity regarding normative regulations that are already in place and can be expected to proliferate in the years ahead. Granted, they are viewing ethical considerations pragmatically. But why not? Why not envision a more equitable world even if it is not yet taken fully into account by every corporate entity? And as for the makers of killer drones, it is perhaps worth mentioning on another pragmatic note that in the not too distant future a company thus engaged can probably shift to harmless, even humanitarian, alternatives without severely disturbing its bottom line.

\section{Conclusion}

There is reliable evidence available that drones are being used to kill civilians, and that these targeted killings often occur outside of any legitimately designated warzone. Political 
leaders who support these killings and even select the targets themselves insist that these killings are not covered by traditional rules of war. Their amoral stance, however, is not unchallenged. In particular, a growing body of investigative reporting and legal analysis opposes these targeted killings of civilians. The principal objection, with respect to international law criteria, is that the drone dispatcher is not itself engaged in a war against those whom it is targeting.

Corresponding to these legal considerations in opposition to drone killing of civilians, there is also a body of literature that raises ethical objections. This literature is not uniform or unanimous in opposition to the ethics of all drone killings, but the majority of commentators on this subject oppose using drones to kill civilians. Some go farther and either urge banning killer drones altogether or pondering very seriously what consequences await the world once killer drones are at the disposal of alien forces of every kind. It merits mentioning, furthermore, that those who favor a total ban should be encouraged by the successful campaigns against land mines and cluster bombs; for, those campaigns each emphasized the inordinate harm to civilians. vi

It might be argued that a company manufacturing these drones need not be concerned about its corporate social responsibility in this regard so long as normative opinion remains divided. But no company can maintain an unblemished public image if and as public sentiment grows more hostile to the killing of civilians. This is unlikely to happen so long as government spin doctors are able to assure the general public that everyone being killed is in some fashion or other an evil-doer out to harm their country. But we would like to think that honorable companies can and will take the lead in identifying rather than obfuscating the bright line between good and evil. Cocaine distributors have no interest in shutting down the drug trade; nor do providers of child prostitution favor constraints on people trafficking. But a drone manufacturer concerned about its social responsibility might very well call into question its involvement in a process that results in the death of civilians. Moreover, its doing so may well be financially easier to absorb now that alternative uses of drones are being developed apace. And if this conversion to peacetime uses should become an industry policy, then the day might come when no drones are marketed to kill people who are not actively opposing one's country.

\section{References}

Ahmed, A. 2013). The Thistle and the Drone: How America's War on Terror Became a Global War on Tribal Islam. Washington, DC: Brookings Institution Press.

Anon. (2015). 'Who will fight the next war?' The Economist, Oct. 24, pp. 25-30.

Benjamin, M. (2011). Drone Warfare: Killing by Remote Control. New York: Verso.

Business Insider (2015). The Drones Report: Market forecasts, regulatory barriers, top vendors, and leading commercial applications, 27 May, online at 
http://www.businessinsider.com/uav-or-commercial-drone-market-forecast-2015-2

Byrne, E. (2014). 'In Lieu of a Sovereignty Shield, Multinational Corporations Should Be Responsible for the Harm They Cause,' Journal of Business Ethics 124(4), 609-621.

Byrne, E. (2010). 'The U.S. Military-Industrial Complex is Circumstantially Unethical,' Journal of Business Ethics 95(2), 153-165.

Byrne, E. (2009). 'Review Article: Just War Theory and Peace Studies,' Teaching Philosophy 32:3, pp. 297-304.

Byrne, E. (2007). 'Assessing the Arms Industry's Corporate Social Responsibility,' Journal of Business Ethics 74(3), 401-417.

Carroll, A. B. (1991). 'The pyramid of corporate social responsibility: toward the moral management of organizational stakeholders,' Business Horizons 34, 39-48.

Carroll, A. B. (1999). 'Corporate social responsibility: evolution of a definitional construct,' Business \& Society 38, 268-95.

Chamayou, G. (2015). A Theory of the Drone, tr. J. Lloyd. New York/London: The New Press. Cohn, M., ed. (2015). Drones and Targeted Killing: Legal, Moral, and Geopolitical Issues. Northampton, MA: Olive Branch Press.

Cortright, D., Fairhurst, R., and Wall, K. Eds. (2015). Drones and the Future of Armed Conflict: Ethical, Legal, and Strategic Implications. Chicago and London: Chicago University Press.

Cronin, A. K. (2015). 'The Strategic Implications of Targeted Drone Strikes for US Global Counterterrorism,' in Cortright et al. (2015), pp. 99-120.

Dillo, C. (2013). “What is the drone industry really worth?" Fortune.com, 12 March, online at http://www.fortune.com/2013/03/12/what-is-the-drone-industry-really-worth/

Draper, K. (2016). War and Individual Rights: The Foundation of Just War Theory. Oxford: Oxford University Press.

Dudziak, M. (2015). 'Targeted Killing and Secret Law: Drones and the Atrophy of Political Restraints on the War Power,' in Cortright et al. (2015), pp. 163-179.

Falk, R. (2015). 'Why Drones Are More Dangerous Than Nuclear Weapons,' in Cohn, ed., pp. 29-49.

Fiala, A. (2008). The Just War Myth: The Moral Illusions of War. Lanham, Boulder, New York: Rowman \& Littlefield.

Finklestein, C., Ohlin, J. D., and Altman, A., eds. (2012). Targeted Killings: Law and Morality in an Asymmetrical World. Oxford: Oxford University Press.

Fotion, N. (2007). War and Ethics: A New Just War Theory. London: Continuum International Publishing Group.

Gardam, J. G. (1993). Non-Combatant Immunity as a Norm of International Law. Dordrecht/Boston/London: Martinus Nijhoff. 
Gardner, L. C. (2013). Killing Machine: The American Presidency in the Age of Drone Warfare. New York and London: The New Press.

Greenberg, K. J. (2015). 'Drone Strikes and the Law: From Bush-Era Detention to Obama-Era Targeted Killing,' in Cortright et al. (2015), pp. 74-87.

Griek, I., van der Linden, A., and Berkleef, T. (2014). 'Drones \& Human Rights: Emerging Issues for Investors.' Sustainalytics. Online at http://www.sustainalytics.com/sites/default/files/drones_issuesforinvestors_may2014.pdf

Grossman, L. (2013). 'Drone Home,' Time, 11 Feb., pp. 27-33.

ICRC (2014). Protecting Civilians and Humanitarian Action through the Arms Trade Treaty. Geneva: International Committee of the Red Cross.

Krieger, M. (2013). 'U.S. Military Changes Drone Rules to Make Targeting of Civilians Easier,' Liberty Blitzkrieg, Dec. 6, online at libertyblitzkrieg.com/2013/12/06/US-military-changesdrone-rules-to-make-targeting-of-civilians-easier/

Living Under Drones: Death, Injury, and Trauma to Civilians from US Drone Practices in Pakistan (2012). New York: NYU School of Law, International Human Rights and Conflict Resolution Clinic, Sept.

Loewenstein, A. (2014). 'Is it possible to run a drone business with an ethical base?' The Guardian, 9 Oct., online at http://www.theguardian.com/commentisfree/2014/oct/10/ls-itpossible-to-run-a-drone-business-with-an-ethical-base

Mayer, J. (2008). The Dark Side: The Inside Story of How the War on Terror Turned into a War on American Ideals. New York: Doubleday.

Melzer, N. (2008). Targeted Killing in International Law. Oxford: Oxford University Press.

Newcome, L. R. (2004). Unmanned Aviation: A Brief History of Unmanned Aerial Vehicles. Reston, VA: American Institute of Aeronautics and Astronautics, Inc.

Nicas, J., and Pasztor, A. (2015). 'U.S. Drone Rules Get Fast-Tracked.' Wall Street Journal, 20 Oct., p. B4.

Norman, R. (1995). Ethics, Killing and War. Cambridge: Cambridge University Press.

O'Connell, M. E., ed. (2012). What Is War? An Investigation in the Wake of 9/11, International Humanitarian Law Series Vol. 37, Leiden/Boston: Brill/Nijhoff.

O'Connell, M. E. (2004). "What Is War?" Jurist, 17 March, online at http://www.jurist.org/forum/oconnell1.php.

Philosophy of Science Portal. 'Drone ethics,' online at philosophyofscienceportal.com/2013/04/drone-ethics.html [accessed 6/13/2014]

Pasztor, A. (2013). 'Drones Get a Lift as FAA Authorizes Tests for Private Use,' Wall Street Journal, 31 Dec., p. A3.

Pasztor, A. (2015). "Drone Fights to Stay Aloft," Wall Street Journal, 12 Oct., p. B3.

Reagan, J. (2015). "Database Reveals Commercial Niche for Military Drones," DroneLife.com, 
23 July, online at dronelife.com/2015/07/23/database-reveals-commercial-niche-formilitary-drones/

Recommendations and Report of the Task Force on US Drone Policy (2014), Gen. J. B. Abizaid (US Army, Ret.) and R. Brooks, Task Force Co-Chairs. Washington, DC: Stimson. Available online at http://www.stimson.org/images/uploads/task_force_report_final_web_062414.pdf Shanker, T. (2013), 'Simple, Low-Cost Surveillance Drones Provide Advantage for U.S. Military,' New York Times, 25 Jan., p. A12.

Singer, P. W. (2009). Wired for War: The Robotics Revolution and Conflict in the $21^{\text {st }}$ Century. New York: Penguin Press.

Stefany, D. (2013). 'Daniel Stefany looks at Drone Warfare,' The Center for the Study of the Presidency \& Congress - Presidential Fellows Blog, online at presidentialfellows.wordpress.com/2013/03/18/daniel-stefany-looks-at-drone-warfare/

Strawser, B. J., ed. (2013). Killing By Remote Control: Ethics of an Unmanned Military. Oxford, UK and New York: Oxford University Press.

Turse, N. (2012). The Changing Face of Empire: Special Ops, Drones, Spies, Proxy Fighters, Secret Bases, and Cyber Warfare, Chicago: Haymarket.

United Nations (2014). The Arms Trade Treaty. Available online at http://www.thearmstradetreaty.or/images/ATT_English.pdf

Van der Linden, H. (2015). 'Drone Warfare and Just War Theory,' in Cohn, M., ed, Drones and Targeted Killing, pp. 169-194.

Walzer, M. (1977). Just and Unjust Wars. New York: Basic Books.

Welsh, J. M. (2015). 'The Morality of "Drone Warfare”, ' in Cortright et al. (2015), pp. 24-45.

Windsor, D. (2006). 'Corporate Social Responsibility: Three Key Approaches,' Journal of Management Studies 43:1, 93-114.

Woods, C. (2015a). Sudden Justice: America's Secret Drone Wars. Oxford, UK and New York: Oxford University Press.

Woods, C. (2015b). "Understanding the Gulf between Public and US Government Estimates of Civilian Casualties,' in Cortright et al. (2015), pp. 180-198.

Zenko, M. (2013). Reforming U.S. Drone Strike Policies. New York: Council on Foreign Relations Center for Preventive Action.

\section{Notes}

i. See Center for the Study of the Drone at Bard College, The Drone Exemptions Database, online at http://www.dronecenterbard.edu. 
ii. Killing innocent civilians is currently the subject of a lawsuit. See Scott Shane, "Families of Drone Strike Victims in Yemen File Suit in Washington,” New York Times, 8 June 2015.

iii. Available online at https://www.icrc.org/customary_ihl/eng/docs/v1_rul_rule89

iv. ICRC, Interpretative Guidance on Direct Participation in Hostilities, Protocol of 8 June 1977 Additional to the Geneva Conventions of 12 August 1949, and Concerning the Protection of Victims of International Armed Conflicts, Article 51(3), online at http://www.icrc.org/applic/ihl/ihl.nsf/INTRO/470?OpenDocument; ICRC, 'Interpretive Guidance on the Notion of Direct Participation in Hostilities under International Humanitarian Law,' International Review of the Red Cross 90, no. 872 (2008), online at http://www.icrc.org/resources/documents/article/review/review-872-F991.htm; ICRC, 'Civilian “direct participation in hostilities”: overview,' online at http://www.icrc.org/eng/war-andlaw/contemporary-challenge-for-ihl/participation-hostilities/overview-direct-participation.htm

v. Boumediene v. Bush et al., 553 U.S. 723 (2008).

vi. Regarding land mines, see the Ottawa Treaty (also called the Anti-Personnel Mine Ban Convention, or simply the Mine Ban Treaty), officially known as the Convention on the Prohibition of the Use, Stockpiling, Production and Transfer of Anti-Personnel Mines and on their Destruction. To date, there are 162 States Parties to the treaty. One state has signed but not ratified (The Marshall Islands) while 34 UN states including the United States, Russia and China are non-signatories, making a total of 35 United Nations states not party. See Wikipedia. Regarding cluster bombs, see the Convention on Cluster Munitions, adopted 30 May 2008 in Dublin, entered into force on 1 August 2010. As of October 2015, 108 states have signed the treaty and 98 have ratified it or acceded to it. The US is not a signatory. 